\title{
Impact of Weather on Agriculture Commodity Market and the Price Discovery:
} An Empirical Analysis

Suraj. E. $\mathrm{S}^{\mathrm{a}^{*}}$, Ojasvi Gupta ${ }^{\mathrm{b}}$

${ }^{a}$ Department of Management Studies, Naipunnya Business School, Pongam, Kerala

${ }^{b}$ Department of BBA, Christ University, Bangalore

*Correspondin Author

\begin{abstract}
This paper focused on studying the agricultural commodity prices in India and it's extreme volatility due to many reasons such as government interference, growth, market forces factors, regular floods and droughts, transport and warehousing problems, etc. These are contributing factors to demand fluctuations. In this case, the future market plays an important role in the economy. The demand for commodity futures has three particular economic functions: price discovery, price risk management, and price volatility. The future market plays a key role in the process of price discovery. The main aim of this system is to regulate prices to minimize uncertainty, to provide price signals to market traders for futures spot prices through the price discovery phase. So, this study emphasized the role of the derivative market in reducing the volatility of agricultural commodity prices in the Indian market.
\end{abstract}

Keywords: volatility, future market, derivatives

\section{Introduction}

This Study provides empirical results on price discovery dynamics of agriculture commodity markets in India. It explains the market efficiency of the major agriculture commodities in the Indian commodity market i.e, Chana, Pepper, Guar gum, Mentha oil, and Wheat. It also focuses on the influence of weather on the price discovery process of the agriculture commodity market. This research has conducted different test models to check the market efficiency of the agriculture commodity market.

India is an agriculture-based nation with the second most important agricultural production position in the world. Indian producers face price threat due to commodity market uncertainty. As a result, commodity futures markets play a major role in the price discovery process to stabilize prices. In the initial stage of growth and development of commodity market, much of the work was done on discovering values for the futures market of agricultural commodities. Therefore, most of the surveys conducted previously are representative of the regional markets. Some of the experiments have been undertaken to check the market efficiency of agriculture commodities markets, which are restricted to a range of particular agriculture commodities markets and a shorter-term mix of agriculture and non-agriculture commodities markets. There is, therefore, a requirement to research the economic efficiency of the commodity market from the point of view of price discovery and uncertainty. This may allow the stakeholders to get an understanding of the price that is likely to prevail at a point and 
time, and therefore they can choose from different competing goods and choose the one that matches them. In India, however, few researches have been carried out in this field of commodity markets, as futures trading began in 2003. Most of the experiments were done when considering non-agricultural commodities. Several experiments have focused on agricultural commodities for a short period. The quality of the commodity market needs to be examined based on price discovery and uncertainty.

None of the previous studies analyzed the performance of the total agriculture commodities in national exchanges. The research thus aims to fill this gap by examining five major agricultural commodities: Chana, Wheat, Guargum, Mentha oil, and Pepper exchanged in national exchanges. This study also helps to know the reasons for volatility in the prices of agricultural commodities in the market.

\section{Review of Literature}

This section focused on establishing the relationship between macroeconomic variables and exchange rate in the developing vs. developed economies. Srinivasn (2011) covers the procedure of price discovery and instability in Indian spot-market through Johansen co-intergration test, Vector Error Correction Model (VECM), and the bivariate EGARCH model. The paper utilizes four future and spot files, speaking to areas like farming, vitality, metal, and composite list of the multi-item trade of India (MCX). The article shows that the core of spot and futures market unpredictability in value revelation has been first reflected in the spot market as opposed to futures market. Dr. Sumathy M ( 2016) tries to identify the price discovery vehicle for spot market movement. The objectives of the study were to test price discovery in the commodity market with significance on the silver and to test the relationship applicable between spot and futures on silver. This article takes into consideration futures and spot prices of silver and the log returns used for analysis purposes. Various tests were undertaken to achieve the objectives namely, the Johansen co-integration test, which indicated that there is one equation available between the spot and futures prices of the silver. The granger causality test indicated that there is no cause and effect relationship between the spot and futures price, meaning that the prices of silver do not show a long-run relationship.

Mrs. Isha Chhajed (2013) examined the market reactions and price discovery in the Indian agriculture markets. The scope of the study was limited to nine agriculture products which were often chosen based on the availability of data and that were actively traded on NCDEX. The period of study was from April 1, 2009, to March 31, 2010, and the data included the monthly average of closing spot and future prices since in some of the cases the data was collected twice, the data which was collected near to the closing time was considered. Two tests were considered to follow up the objectives, namely the Granger causality test, to examine the price discovery, and backwardation and contango, to examine the market behavior of the agriculture commodity market. The aftereffect of the study indicates that the price discovery instrument is very extraordinary for various products however it recommends that causality could be utilized in gauging spot and futures prices. The study also points out various areas that affect the price discovery in the commodity market but are not considered like seasonal cycles and asset storability. The study concludes with the fact that if changes in spot prices affect the future prices, effective hedging strategies can be structures; whereas if changes in future prices have an effect of spot prices, effective speculation strategies can be created. 
Garbade (1983) examined the qualities of value improvements in real money (or spot) markets and prospects markets for storable wares. Region II pre-sents an illustrative demonstration of synchronous value components which suggests that, over brief interims of time, the relationship of cost changes could be an element of the adaptability of exchange between the physical item and its accomplice prospects contract. This likewise is by all accounts the case with gold, even though information constraints forestall an indisputable proclamation. The valuing of silver and particularly oats and copper are all the more uniformly isolated between the money and fates markets.

Vijayshankar (2012) gives basic points of view on a few of the strengths that are effectively forming the structure and social connections of product markets in India nowadays. They emphasize the significance of a layered, commodity-based, and region-specific understanding of markets. Ward (1996) objective is to utilize FCMS data to pick up a distant better understanding of price disclosure within the nourished cattle showcase. Solidification among bigger agriculture firms limits gets to exchange data vital for a few sorts of cost discovery investigate. The FCMS was created to provide an advertising system and organization structure in which advertise members make personal decisions in an exploratory reenactment environment. Barclay (2003) focuses on the impacts of exchanging after hours on the sum and timing of price disclosure over the 24-hour day. Hence costs are more effective and more data is uncovered per hour amid the exchanging day than after hours. Person exchanges contain more data after hours than amid the day. Trading after hours varies altogether from exchanging amid the day. Exchanging volume after hours is less, showcase creators at times yield firm cites, and exchanging costs are four to five times higher than amid the exchanging day.

Declerck (2014) understands the stock performance of processing companies in terms of product production on commodity markets. The results indicate that food company stock prices do not rely substantially on agricultural market prices. Therefore, the threats of agricultural market price fluctuations can not be hedged by food company stocks whose shares are more liquid. In the scenario of wheat, food processor's share prices do not depend substantially on agricultural market prices. Therefore, the prices of agricultural markets cannot be offset by the stock prices of food processors. More experiments will be performed with other agricultural commodities, oil, and mineral resources. Bohl (2018) studied the relationship between the selected set of agricultural commodities and concluded that speculative activity lowers the noise level in the futures market and also increasing the relative contribution of the future market to the price discovery method. The findings of the study also suggest activities like gambling increases the price discovery of futures markets in two ways. First, speculation reduces the level of volatility included in future prices. Second, speculative activity increases the rate at which future prices reflect new information on changes in market fundamentals. Alternatively, hedgers are found to reduce the ability of futures markets to absorb new information. Therefore, in comparison to hedgers, speculators tend to be more educated and transact with a stronger focus on potential changes in fundamental values.

Seth (2018) examined the on-the-spot and futures market for wheat in India's price discovery and volatility. Results are evaluated using unit root test, Granger causality test, Johansen cointegration test, Vector Error Correction Model (VECM), and Glosten Jagannathan- Runkle Generalized Autoregressive Conditional Heteroskedasticity (GJR-GARCH) model to calculate price discovery and volatility spillovers. Granger's causality test confirms that there is bi-directional 
causality between the wheat spot and the underlying wheat futures market. Radha (2017) analyzes the efficacy of the Indian futures market in price discovery and in alleviating the risk of agricultural commodities as a result of a substantial price rise in recent times. The Johansen Co-integration Test, the Vector Error Correction Model (VECM), and the Granger Causality Test are used to explain the relationship between spot and potential values. The optimal hedge ratio and hedging efficiency were determined using VECM. The results reflect the co-integration of spot and futures markets for all four goods under near-month and near- month contracts.

Kumar (2014) made an analysis of price disclosure and volatility distribution in Indian commodity markets. The analysis used four futures and found MTSM indices. The study also uses the Vector Error Correction Model (VECM) and the Two-Dimensional Exponential Algorithm (EGARCH) model to evaluate the price disclosure and uncertainty distribution in the Indian spot market for the foreseeable future. Innovations in one market can predict volatility in another market. Chen (2017) investigated the effects of market discovery and the distribution of variation between agricultural ETPs and the underlying commodity. The historical prices of the five most common ETP grains and their related products are calculated using the VEC and BEKK models. Findings indicate a unidirectional association between the ETPs and the underlying ones, particularly in the short term.

Gupta (2018) empirically examined long-term market performance and price discovery in the Indian commodity futures market. The research included eight commodities, including two agricultural commodities, two production commodities, two precious metals, and two petroleum commodities. The presence of short-term expectations in the Indian futures market is shown by the results of the VECM model indicating a lack of insightful performance. The statistically relevant significance of past and future costs demonstrates short-term inefficiency and bias. The substantial importance of the error correction word (ECT) for future prices shows that commodity futures are the most important predictor of commodity price fluctuations. Brorsen (1984) studied the relationship between everyday cash and future values, using time series analysis. The method includes the check of causality between the two price sequences. The findings suggest that potential demand changes corresponding to cash rates, suggesting that values are found in the futures market.

\section{Research Methodology}

\subsection{Objectives of the Study}

1. To study the impact of fluctuations in weather on different agricultural commodity prices over five years.

2. To study the root causes of the price volatility of agricultural commodties.

\subsection{Sources of Data}

The sample population for the secondary data includes the commodities exchanged at known commodity exchanges in India. The production cycle varies between goods based on the existence of future price evidence. The commodities included are Chana, Wheat, Guar gum, Mentha oil, and Pepper which are taken as the dependent variables. The monthly average values of spot markets of all of these commodities are collected from the multi-commodity exchange from January 2015 to December 2019. The timeframe taken is the same for all the five mentioned commodities. Weather conditions are also recorded for five years, taking the monthly average per year, which are considered as independent variables. 


\subsection{Statistical Tools Used for the Study}

The data analysis includes descriptive statistics, stationarity or unit root test, augmented dickey fuller test, ordinary least square test, and autoregressive conditional heteroskedasticity (ARCH) model.

\subsubsection{Transformation of Data Set}

In the case of Stationarity, the data set is transformed into distinct data. The explanation for this is to remove the pattern variable from the time series to make Stationarity. So when time series raw data is transformed, non-stationary data will immediately become stationary. After conversion, the data should be graphically checked to see if there are outliers or not.

\subsubsection{Stationarity or Unit Root Test}

Many financial time series data are non-stationary. It means that it has a pattern meaning over a while. But if using financial models like Johansen Co-integration, Granger Causality, GARCH, VECM, etc., non-stationary data cannot be used because these models can only be used for stationary results. So we need to use non-stationary data in stationary data. It can be done with the help of the Unit Root Test through Augmented Dickey-Fuller and Phillip Perron Test. If the data series is nonstationary at level I(0) form, it becomes stationary at I (1) or 1st difference or 2nd difference and so on. If the data set has a pattern activity, it must be deterred to make it Stationarity to continue with the further process. The Stationarity of the time series is checked to avoid spurious regressions.

\section{Analysis}

This study shows the empirical results on price discovery dynamics of agriculture commodity markets in India. It explains the market efficiency of the major agriculture commodities in the Indian commodity market, i.e Chana, Pepper, Guar gum, Mentha oil, and Wheat. It also identifies the influence of weather on the price discovery process of the agriculture commodity market. To test the market efficiency of the commodity market, various tests such as the ARCH test, Heteroskedasticity tests were conducted on the data collected. Descriptive statistics of each commodity price detail are given below.

\begin{tabular}{|c|c|c|c|c|c|}
\hline \multicolumn{7}{|c|}{ Table 1.1. Descriptive Statistics of Commodity price (SPSS) } \\
\hline STATISTICS & WHEAT & PEPPER & $\begin{array}{c}\text { MENTHA } \\
\text { OIL }\end{array}$ & $\begin{array}{c}\text { GUAR } \\
\text { GUM }\end{array}$ & CHANA \\
\hline Mean & 0.510 & -0.612 & 0.835 & -0.604 & 0.466 \\
\hline Median & 0.403 & -0.667 & 0.163 & -0.819 & -0.205 \\
\hline Maximum & 12.735 & 13.418 & 26.861 & 22.378 & 230.608 \\
\hline Minimum & -9.280 & -14.824 & -13.997 & -20.564 & -232.012 \\
\hline Std. Dev. & 3.366 & 5.545 & 7.359 & 8.536 & 43.943 \\
\hline Skewness & 0.163 & 0.344 & 1.398 & 0.399 & -0.082 \\
\hline Kurtosis & 6.104 & 3.213 & 6.302 & 3.572 & 26.944 \\
\hline Jarque-Bera & 23.958 & 1.281 & 46.059 & 2.37 & 1409.559 \\
\hline Probability & 0.000006 & 0.526 & 0.000 & 0.305 & 0.000 \\
\hline Sum & 30.141 & -36.108 & 49.276 & -35.683 & 27.497 \\
\hline Sum Sq. Dev & 657.384 & 1783.602 & 3141.084 & 4226.633 & 112002.3 \\
\hline Observations & $\mathbf{5 9}$ & $\mathbf{5 9}$ & $\mathbf{5 9}$ & $\mathbf{5 9}$ & $\mathbf{5 9}$ \\
\hline
\end{tabular}


Source: SPSS

Figure 1.1. The Skewness of Commodity Prices

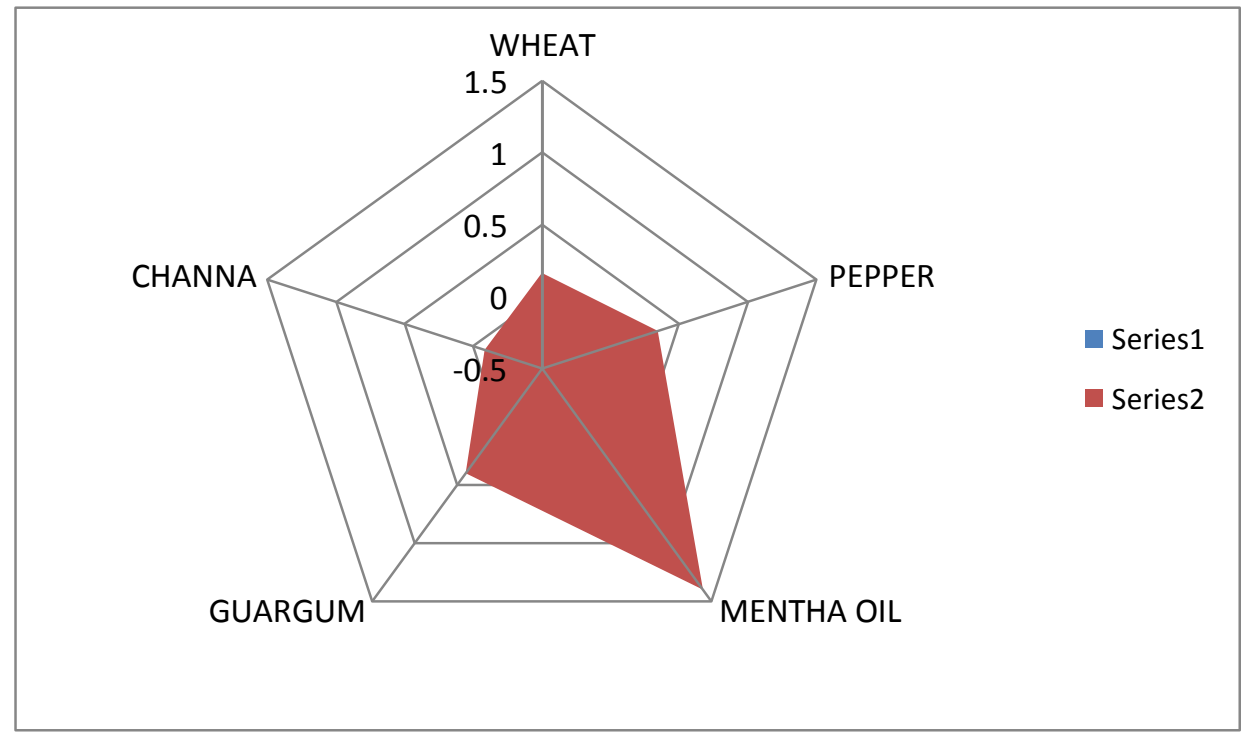

Source: www.rbi.org.in

It can be observed that the skewness is highly skewed in Mentha oil with 1.3 as its value, while the rest of the commodities value lies between -0.5 and 0.5 , so we can conclude that the distribution is symmetric. Mentha oil commodity prices are highly volatile. Slower demand from the consuming industries in the spot market put pressure on Mentha oil price leading to volatility. Most of the speculators avoided fresh positions following low demand in the Indian spot market for this commodity, but Mentha crop is likely to rise in 2020-21 on expectations of the sowing area to increase for the new season. In recent years, besides traditional growers of UP, farmers in Madhya Pradesh have also started cultivating mentha crops due to better returns. Even though the prices have fallen, traditional UP people will continue with Mentha cultivation due to the attractive returns from the mint crop which is almost double the cost of production. Cold waves and heavy rains are harmful during the leaf formation of Mentha Oil, which leads to higher volatility in the future. In the past, India was an export place for Mentha Oil and its derivatives. This leads the exporters to face the volatility of commodity prices. Due to the presence of a contrct on liquid futures on MCX, participants will be able to hedge the Mentha Oil on the MCX platform.

\begin{tabular}{|c|c|c|c|c|c|}
\hline \multicolumn{6}{|c|}{ Table 1.2. Descriptive Statistics of Weather on Yearly Basis (SPSS) } \\
\hline STATISTICS & $\mathbf{2 0 1 5}$ & $\mathbf{2 0 1 6}$ & $\mathbf{2 0 1 7}$ & $\mathbf{2 0 1 8}$ & $\mathbf{2 0 1 9}$ \\
\hline Mean & 80.170 & 76.383 & 74.690 & 74.127 & 75.389 \\
\hline Median & 80.970 & 74.730 & 74.970 & 74.280 & 74.690 \\
\hline Maximum & 84.150 & 89.460 & 81.830 & 79.640 & 82.480 \\
\hline Minimum & 75.210 & 67.090 & 68.620 & 68.320 & 67.450 \\
\hline Std. Dev. & 3.069 & 6.243 & 4.144 & 3.227 & 4.562 \\
\hline Skewness & -0.496 & 0.689 & 0.096 & -0.065 & -0.096 \\
\hline Kurtosis & 1.857 & 2.826 & 2.113 & 2.321 & 2.198 \\
\hline Jarque-Bera & 1.145 & 0.965 & 0.411 & 0.238 & 0.339 \\
\hline Probability & 0.564 & 0.617 & 0.814 & 0.887 & 0.843 \\
\hline Sum & 962.050 & 916.600 & 896.290 & 889.530 & 904.670 \\
\hline
\end{tabular}




\begin{tabular}{|c|c|c|c|c|c|}
\hline Sum Sq. Dev & 103.662 & 428.767 & 188.980 & 114.616 & 228.997 \\
\hline
\end{tabular}

Source: SPSS

Weather shocks affect the supply of agricultural commodities and their prices. It was found that the effect of weather on agricultural commodity prices is normal in all years except in 2016. In 2016, the data distribution is moderately skewed, while for the rest of the years, the distribution is approximately symmetrical.

\begin{tabular}{|c|c|c|c|}
\hline \multicolumn{4}{|c|}{ Table 1.3. Stationarity Test of Weather for 2019 (Recent Year)(SPSS) } \\
\hline Particulars & Test Stat & T Statistics & Probability \\
\hline $\begin{array}{c}\text { Augmented Dickey-Fuller test } \\
\text { statistic }\end{array}$ & & -3.860821 & 0.0019 \\
\hline \multirow{2}{*}{ Test critical values: } & $1 \%$ level & -2.886101 & \\
\cline { 2 - 4 } & $5 \%$ level & -1.995865 & \\
\cline { 2 - 4 } & $\begin{array}{c}10 \% \\
\text { level }\end{array}$ & -1.599088 & \\
& & & \\
\hline
\end{tabular}

Source: SPSS

A stationarity test on Weather (Independent Variable) has been conducted for 2019. The weather is stationary at the first and second levels of difference. Also, the value is less than the significant level of 0.05 . Therefore, we can conclude that the data set does not have any long-run relationship, while a short-run relationship may exist and there is no need for cointegration estimation.

\begin{tabular}{|c|c|c|c|c|c|}
\hline \multicolumn{7}{|c|}{ Table 1.4. Stationarity Test of Commodity Prices(SPSS) } \\
\hline STATISTICS & Chana & Guargum & Wheat & Pepper & Mentha oil \\
\hline $\begin{array}{c}\text { Augmented } \\
\text { Dickey } \\
\text { Fuller Test }\end{array}$ & -12.115 & -6.325 & -5.7212 & -8.772 & -5.906 \\
\hline 1\% Level & -3.548 & -3.548 & -3.548 & -3.548 & -3.548 \\
\hline 5\% Level & -2.912 & -2.912 & -2.912 & -2.912 & -2.912 \\
\hline 10\% Level & -2.594 & -2.594 & -2.594 & -2.594 & -2.594 \\
\hline
\end{tabular}

Source: SPSS

Stationarity test - unit root test for the dependent variable (Chana) is conducted.

Ho- Data is stationarity.

H1-Data doesn't have stationarity.

The ADF test statistic is greater than the test critical values at $1 \%, 5 \%$, and $10 \%$ level after ignoring the negative sign and, at the same time, the probability is $0 \%$ which is less than $5 \%$ which implying that the null hypothesis could be rejected for all products. Further, the data shows stationarity, as the statistical properties of the data set do not change over time. Therefore, it can be concluded that the data has stationarity at the level.

\section{Heteroskedasticity Test}

Before applying the ARCH class of methodology, it is essential to inspect closely the residuals for heteroskedasticity. To test the existence of heteroskedasticity in residuals of agriculture commodities and weather log series, the heteroskedastic test is applied to determine the ARCH effect 
from 2015 to 2019.

\begin{tabular}{|c|c|c|c|c|c|c|}
\hline \multicolumn{7}{|c|}{ Table 1.5. Heteroskedasticity Test (SPSS) } \\
\hline Commodity & $\begin{array}{c}\text { Heteroscedasticity } \\
\text { Test }\end{array}$ & $\mathbf{2 0 1 5}$ & $\mathbf{2 0 1 6}$ & $\mathbf{2 0 1 7}$ & $\mathbf{2 0 1 8}$ & $\mathbf{2 0 1 9}$ \\
\hline \multirow{3}{*}{ Chana } & F statistic & 2.0462 & 0.105 & 0.107 & 0.263 & 0.052 \\
\hline \multirow{3}{*}{ Guargum } & Prob F(1.8) & 0.1905 & 0.753 & 0.751 & 0.621 & 0.824 \\
\hline \multirow{3}{*}{ Wheat } & F statistic & 0.437 & 0.320 & 0.320 & 3.091 & 0.027 \\
\cline { 2 - 7 } & Prob F(1.8) & 0.527 & 0.586 & 0.587 & 0.116 & 0.872 \\
\hline \multirow{3}{*}{ Pepper } & F statistic & 0.254 & 0.019 & 0.189 & 0.265 & 0.106 \\
\hline & Prob F(1.8) & 0.627 & 0.893 & 0.674 & 0.620 & 0.752 \\
\cline { 2 - 7 } Menthol oil & F statistic & 0.039 & 0.068 & 0.133 & 0.219 & 0.182 \\
\cline { 2 - 7 } & Prob F(1.8) & 0.847 & 0.799 & 0.724 & 0.652 & 0.680 \\
\hline
\end{tabular}

Source: SPSS

The heteroskedasticity test is done before conducting the ARCH test, as it is necessary to check closely the residuals for heteroskedasticity. In the above scenario, the independent variable is the weather while commodity prices of Chana, Guar gum, Wheat, Pepper, Mentha oil are the dependent variable. Since the probability value (p-value) is higher than $5 \%$, the null hypothesis of no ARCH effect is accepted at the level of significance, showing the non-presence of ARCH effects in the residuals of time series-models. From applying the test to the data set, it is observed that the data describes a situation wherein the relationship between the independent variable (weather) and dependent variable(agriculture commodities) is not the same across all values of the weather. All the dependent variables - Chana, Mentha oil, Guar gum, Wheat, and Pepper are stationary at level and intercept only.

\begin{tabular}{|c|c|c|c|c|c|}
\hline & Chana & Guargum & Mentha oil & Pepper & Wheat \\
\hline 2015 & $\begin{array}{c}0.36 \\
\text { (weak) }\end{array}$ & $\begin{array}{c}0.33 \\
\text { (weak) }\end{array}$ & $\begin{array}{c}0.07 \\
\text { (very weak) }\end{array}$ & $\begin{array}{c}0.14 \\
\text { (very weak) }\end{array}$ & $\begin{array}{c}0.04 \\
\text { (very weak) }\end{array}$ \\
\hline 2016 & $\begin{array}{c}0.4 \\
\text { (weak) }\end{array}$ & $\begin{array}{c}0.37 \\
\text { (weak) }\end{array}$ & $\begin{array}{c}0.46 \\
\text { (weak) }\end{array}$ & $\begin{array}{c}0.00 \\
\text { (very weak) }\end{array}$ & $\begin{array}{c}0.46 \\
\text { (weak) }\end{array}$ \\
\hline 2017 & $\begin{array}{c}0.49 \\
\text { (weak) }\end{array}$ & $\begin{array}{c}0.56 \\
\text { (moderate) }\end{array}$ & $\begin{array}{c}0.28 \\
\text { (very weak) }\end{array}$ & $\begin{array}{c}0.04 \\
\text { (very weak) }\end{array}$ & $\begin{array}{c}0.23 \\
\text { (very weak) }\end{array}$ \\
\hline 2018 & $\begin{array}{c}0.44 \\
\text { (weak) }\end{array}$ & $\begin{array}{c}0.7 \\
\text { (strong) }\end{array}$ & $\begin{array}{c}0.33 \\
\text { (weak) }\end{array}$ & $\begin{array}{c}0.05 \\
\text { (very weak) }\end{array}$ & $\begin{array}{c}0.22 \\
\text { (very weak) }\end{array}$ \\
\hline 2019 & $\begin{array}{c}0.39 \\
\text { (weak) }\end{array}$ & $\begin{array}{c}0.44 \\
\text { (weak) }\end{array}$ & $\begin{array}{c}0.39 \\
\text { (weak) }\end{array}$ & $\begin{array}{c}0.03 \\
\text { (very weak) }\end{array}$ & $\begin{array}{c}0.27 \\
\text { (very weak) }\end{array}$ \\
\hline
\end{tabular}

Source: SPSS

The above table 1.6 indicates the summary of the Ordinary least squares test where the 
various agricultural commodities were compared with the independent variable-weather. It can be seen that there are lesser chances to find simple linear regression for Chana in the subsequent years while being worse in 2019. While in case of pepper and wheat there seems to be no linear regression formation in any of the years. In case of Guar gum, a strong relationship could be formed in 2018 and moderate in 2017. So it was concluded that out of 5 commodities, weather effect on the prices of Guar gum was significant in the recent years. There was no simple linear regression for other commodities (Chana, Pepper, Mentha oil, Wheat) in the commodity market which is related to weather.

\section{Scope of Further Research}

Research can be undertaken by comparing Indian agricultural commodities with the international agricultural commodity futures market. The current study is restricted to the price discovery function; it can be extended by taking into consideration the risk management function. Studies can be conducted for other agricultural commodities traded in the Indian commodity market. Research can also be conducted to study the impact of rainfall, exchange rate, wholesale price index, and demand and supply on the agriculture price index.

\section{Conclusion}

The present study focused on the price discovery dynamics of agriculture commodity markets in India. It was found that mentha oil commodity prices are highly volatile due to the slower demand from the consuming industries in the spot market that has put pressure on mentha oil price, leading to volatility. Ordinary Least squares comparison of 5 commodities showed that weather effect on the prices of Guar gum was significant in the recent years, but there was no simple linear regression for other commodities (Chana, Pepper, Mentha oil, Wheat) in the commodity market which is related to weather on commodity prices in Indian Market. Stationarity was also seen in the dependent variables: Chana, Pepper, Mentha oil, Guar gum, and Wheat. The ARCH test was possible to be conducted since the period considered was five years only. Furthermore, a new variable was considered in the current study (weather) which too impacted the heteroskedasticity of the data. It is observed that since the data collected in the current study was monthly averaged, the numbers of observations for conducting tests were less and, therefore, the probabilities and critical values calculated may not be very accurate. For protecting agricultural producers from the price volatility of Mentha oil, weather insurance schemes can be introduced. Investments in crop breeding and agronomic research need to be made to establish new crop cultivators that are immune to promoting water-effective crop production technologies to make the agricultural commodity market more efficient. The findings of this study will be useful to producers for managing price risk and for traders to utilize speculative and arbitrage opportunities for Mentha Oil.

\section{Reference}

[1] Alphonse. (2000). Efficient price discovery in stock index cash and futures markets. Annales d'Économie et de Statistique, 60, 177-188. https://doi.org/10.2307/20076259

[2] Barclay, M. J., \& Hendershott, T. (2003). Price discovery and trading after hours. Review of Financial Studies, 16(4), 1041-1073. https://doi.org/10.1093/rfs/hhg030

[3] Bohl, M. T., Siklos, P. L., Stefan, M., \& Wellenreuther, C. (2020). Price discovery in 
agricultural commodity markets: Do speculators contribute? Journal of Commodity Market, 18, Article 100092. https://doi.org/10.2139/ssrn.3407686

[4] Brorsen, B., Richardson, J., \& Von Bailey, D. (1984). Investigation of price discovery and efficiency for cash and futures cotton prices. Western Journal of Agricultural Economics, 9(1), 170-176. https://www.jstor.org/stable/40987646.

[5] Chen, Y. (2017). Price discovery and volatility spillover effects: The agricultural ETPS and their underlying commodities [Publishe master's thesis, South Dakota State University]. Electronic Theses and Dissertations. https://openprairie.sdstate.edu/etd/1142/

[6] Chhajed, I., \& Mehta, S. (2013). Market behavior and price discovery in Indian agriculture commodity market. International Journal of Scientific and Research Publications, 3(3), 1. http://www.ijsrp.org/research-paper-0313/ijsrp-p15144.pdf

[7] Commodity futures in India : (2007, March 31). Economic and Political Weekly. https://www.epw.in/journal/2007/13/banking-and-finance-2007-money-special-issuesspecials/commodity-futures-india.html

[8] Declerck, F. (2014). Do agricultural commodity firm stock price and agricultural commodity price move together? International Journal on Food System Dynamics, 5(3), 1-10. doi:10.22004/ag.econ.198962

[9] Garbade, K. D., \& Silber, W. L. (1983). Price movements and price discovery in futures and cash markets. The Review of Economics and Statistics, 65(2), 289. https://doi.org/10.2307/1924495

[10] Guar Gum Refined Splits. (2019). National Commodity \& Derivatives Exchange Limited. https://ncdex.com/products/GUARGUM5

[11] Gupta, S., Choudhary, H., \& Agarwal, D. R. (2018). An empirical analysis of market efficiency and price discovery in Indian commodity market. Global Business Review, 19(3), 771-789. https://doi.org/10.1177/0972150917713882

[12] Kumar Mahalik, M., Acharya, D., \& Suresh Babu, M. (2014). Price discovery and volatility spillovers in futures and spot commodity markets. Journal of Advances in Management Research, 11(2), 211-226. https://doi.org/10.1108/jamr-09-2012-0039

[13] Menkhaus, D. J., Phillips, O. R., Johnston, A. F. M., \& Yakunina, A. V. (2003). Price discovery in private negotiation trading with forward and spot deliveries. Review of Agricultural Economics, 25(1), 89-107. https://doi.org/10.1111/1467-9353.00047

[14] Ordinary Least Squares Regression (OLS). (2019). XLSTAT. https://www.xlstat.com/en/solutions/features/ordinary-least-squares-regression-ols

[15] Pepper. (2019). National Commodity \& Derivatives Exchange Limited. https://ncdex.com/products/PEPPER

[16] Radha, K., \& Balakrishnan, S. (2017). The role of commodity futures in risk management: A study of select agricultural commodities. IUP Journal of Financial Risk Management, 
14(4), 7-29.

https://search.proquest.com/openview/b6f5cf078bad090d28d015958f7d6866/1?pqorigsite $=$ gscholar $\& \mathrm{cbl}=54459$

[17] Seth, N., \& Sidhu, A. (2018). Price discovery and volatility spillovers in Indian wheat market: An empirical analysis. IUP Journal of Applied Finance, 24(2), 5-20. https://search.proquest.com/openview/d9c83a94e24d76533cbd265f4f4967bb/1.pdf?pqorigsite $=$ gscholar $\& \mathrm{cbl}=54442$

[18] Sridhar, L. S., Sumathy, M., Sudha, N., \& Charles, A. (2016). Price discovery in commodity market - An empirical study on the silver market. IOSR Journal of Economics and Finance (IOSR-JEF), 7(2), 88-95. https://doi.org/10.9790/5933-0702038895

[19] Srinivasan, P. (2011). Price discovery and volatility spillovers in Indian spot-futures commodity market. The IUP Journal of Behavioral Finance, 9(1), 70-85. https://mpra.ub.uni-muenchen.de/47412/

[20] Understanding agricultural commodity markets: (2012, December 20). Economic and Political Weekly. https://www.epw.in/journal/2012/52/review-rural-affairs/understandingagricultural-commodity-markets.html

[21] Ward, C. E., Koontz, S. R., Peel, D. S., \& Trapp, J. N. (1996). Price discovery in an experimental market for fed cattle. Applied Economic Perspectives and Policy, 18(3), 449-466. https://doi.org/10.2307/1349628

[22] Wheat. (2019). National commodity \& Derivatives Exchange Limited. https://ncdex.com/products/WHEATFAQ

[23] Zapata, H. O., \& Fortenbery, T. R. (1996). Stochastic interest rates and price discovery in selected commodity markets. Applied Economic Perspectives and Policy, 18(4), 643-654. https://doi.org/10.2307/1349596 